\title{
Geographical indications contributions for Brazilian agribusiness development
}

\author{
Luan Carlos Santos Silva ${ }^{1}$, João Luiz Kovaleski ${ }^{2}$, Silvia Gaia ${ }^{2}$, Luani Back ${ }^{2}$, Cassiano Moro \\ Piekarski ${ }^{2}$ and Antônio Carlos de Francisco ${ }^{2}$
}

\begin{abstract}
${ }^{1}$ Department of Production Engineering, Federal University of Rio Grande do Sul (UFRGS), Porto Alegre-RS, Brazil, ${ }^{2}$ Department of Production Engineering, Federal University of Technology - Paraná (UTFPR), Ponta Grossa-PR, Brazil.
\end{abstract}

Accepted 9 May, 2013

\begin{abstract}
This paper aims at analyzing the evolution of deposits and certifications granted as Geographical Indications in Brazil. It also analyses their contributions to the development of the national agrobusiness. The methodological procedures included an exploratory study and a documentary analysis. The data were collected directly from the National Institute of Industrial Property (INPI), taking into account the information available in the last 14 years. Taking into consideration the Brazilian system, this theme is still recent, therefore, it is necessary a better understanding and its socialization both in Academic and Business world. Through such research, it was possible to observe that Geographical Indications have been increasing, although there are still some difficulties to be overcome before they are accepted into industrial property system. However, granted geographical indications contributed to national and international agribusiness development.
\end{abstract}

Key words: Certifications, geographical indications, industrial property, agribusiness.

\section{INTRODUCTION}

There are some intrinsic and extrinsic attributes which represent a "quality badge", features or characteristics that cannot be proven by the consumer before or after purchasing. "The consumer must rely on information provided on the packaging, the media and other forms of communication" (Darby and Karni, 1973). In order to ensure consumers reliability of the products, certificates are developed (Lopes and Santos, 2007). However, the perceived quality of products depends on a communication process that involves both the credibility of the source and the ability of consumer's perception. This variability implies a big challenge: how to adapt the production of agribusiness for the growing demand of the population maintaining the sustainability and profitability (Batt and Dean, 2000; Orth and Krska, 2002; Jover et al.,
2004; Aroeira et al., 2009).

Agricultural products usually have qualities that derive from their place of production. When this relationship is explained by the establishment of a geographical indication (Gl), a certification seal is obtained, giving credence to such product (Aurier et al., 2005; Fandos and Falvián, 2006; Rangnekar, 2011; Mérel and Sexton, 2011; Menapace and Moschini, 2012). The conceptual approach on the issue of $\mathrm{Gl}$ should be put in evidence to show how this tool aims to achieve an appreciation of the traditions, customs, knowledge, practices and other intangible assets associated with a territorial identity and geographic origin (Bérard and Marchenay, 2008; Charlier and Ngo, 2012; Mancini, 2013; Tehrani and Manap, 2013). In this sense, Gls are recognized as a qualification 
strategy that emphasizes the socio-cultural territory where the product is produced, ensuring the development of agribusiness.

By qualifying intangible assets that are difficult to transfer to other territories, Gls can be conceptually understood as a catalyst for processes and endogenous territorial development (Allaire and Sylvander, 1997; Cerdan and Vitrolles, 2008), establishing itself as a counterpoint to general dynamics of the agri-food system in terms of standardization, globalization and market concentration (Benko and Pecqueur, 2001; Azevedo et al., 2012; Jacobs and Zulu, 2012).

In Brazil, according to Article 176 of the Industrial Property Law (IPL) No. 9.279/96, it constitutes a geographical indication or designation of origin. The law also determines that it will be the National Institute of Industrial Property (INPI) which will establish the conditions for the proper registration of Gls under Resolution No. 75/2000.

In Article 2 of the INPI Resolution No. 75/00 28.11.2000, it is considered the Indication of Source, the geographical name of a country, city, region or locality which has been known as a center of extraction, production or manufacture of a product or providing service. And it is considered Designation of Origin, the geographical name of a country, city, region or locality which designates a product or service whose qualities or characteristics are due exclusively or essentially to the geographical environment, including natural and human factors.

According to Article 3 of the same resolution, the protection will extend to graphical or figurative representation of $\mathrm{GI}$, as well as the geographical representation of country, city, region or locality whose name is a geographical indication.

This research is justified by the prominence of Gls in the Brazilian scenario as a way of developing agribusiness. One of the goals of this system is to authenticate information to the consumer, including geographical origin, describing qualities or characteristics arising from this source, as well as protection for products and services of a particular country, city, region or locality against false geographical indications.

This research brings into discussion reflections on the understanding of Gls within the industrial property, taking into account their characteristics and ways to acquire this certification. Since the main objective was to analyze GI as a strategy for the development of agribusiness in Brazil, the research question was: How can Gls develop agribusiness?

\section{Benefits of geographical indications}

Geographical Indications are instruments of public appreciation of the qualitative characteristics of food products coming from a particular geographical area bounded by criteria tradition and productive vocation.

While creating a Gl, two types of motivation are usually involved: firstly, it can arise as a reaction to the loss of quality of a product perceived as a traditional region, either by excessive widening of production area or by usurping its designation. This last action can be identified by deviations from traditional know-how, usually associated with a parallel industrial development. On the other hand, it may come from a desire of the Community assertion of local identity through the revitalization of customs and traditions.

Regulatory protection and commercial valorization of products policy was conceived as a compensation for economic disadvantages of certain disadvantaged areas, and thus it is considered a mere instrument of agricultural development and defense of the income of certain categories of farmers (Nicolas and Valceschini, 1993).

Nowadays, traditional products are also part of a strategy for diversifying economic activity, conquering foreign markets and combating competition from imported products. It is the policy for agribusiness in Brazil (Lopes Neto et al., 2008).

The main objective of a $\mathrm{Gl}$ is the protection of products originated by it, as well as its geographical designation (Tonietto, 1993). According to this author, this benefits both producers, who have commercial interests and are subject to compliance with a set of production rules, and consumers, who have the origin authenticity guaranteed and a minimum standard of quality, as well. Therefore, the legal protection is one of the major benefits provided by the Gl Registry, both from the point of view of producers and consumers.

In Brazil, crimes against Gls are established by Law 9279/1996, Articles 192 to 193. It allows the right holder to take action against those who are manufacturing, importing, exporting, selling, displaying, offering for sale or keeping in stock products that present a false Gl; against those who use or disclose amid indicative terms without advertising in order to safeguard the true origin of the product, and finally, against those who use any signs indicating a false origin, selling or exposing such products (Brazil, 1996).

Products (or services) covered by a GI, by absorbing peculiarities, whether related to natural factors (such as soil, climate and topography) and/or human factors (such as know-how, tradition or culture of a particular community) become differentiated, unique products (Bruch, 2008). Thus, $\mathrm{Gl}$ can also be seen as an alternative to adding value and differential to the production chain, being a competitive strategy based on territorial identities associated with a particular product. This strategy of qualitative differentiation collectively adopted by farmers ensures higher prices as a function of typical productions (Brazil, 2008).

Chaddad (1995) noted that agribusiness of specialties is an important segment to be benefited by the use of names, since it deals with differentiated products with 
high added value, with lower production volume and serving niche markets. The high value and quality of specialties justify designation as a viable tool to efficiently communicate these features to the consumer.

Furthermore, Gl facilitates market presence and product characteristic that feel less competition with others who have lower price and quality (Pistorello, 2006). Furthermore, according to this author, Gl improves product demand, creating consumer confidence. Consumers who hope to find quality product with specific characteristics under the designation of origin label.

According to Bruch (2008), one of the most important objectives of the $\mathrm{Gl}$ is achieving recognition for the place of the product origin which is established by the history of that region and the people who inhabit in it, including its culture, reputation and consistency. This recognition, for the author, not only guarantees the market for the product, but the permanence of those people in place, cultivating habits passed from father to son and ensuring sustainable development of those communities that often would lessen when children leaves to the city, culminating into a complete loss of memory cultivated over generations.

Although, Gls were not designed to promote regional development, they seem to serve as a tool for this, since they represent a possibility to ensure the sustainability of a given region, without incurring its transformation into an industrial hub or a region of monoculture (Bruch, 2008). Bruch also states that $\mathrm{Gl}$ creates a link between a product and its source region, becoming a tool of collective producers to promote their products and territories. However, strategies and projects for the territory are necessary, as well as the participation of local stakeholders, which should mobilize ownership and use different skills to achieve their ends. In this regard, it is noteworthy that each area is different from the other and has its own identity (Paula, 2004).

The strategies for its development, therefore, must be drawn for each reality, considering networks of local actors, natural resources, existing infrastructure, and human capital, entrepreneurship actors, talent and opportunities of the territory. The combination of all these features is unique and inimitable.

Gls can also allow better distribution of value added along the production chain, from the producer of raw materials to the manufacturer, including the possibility of creating jobs. Allow, in some cases, maintain and develop activities in disadvantaged rural areas, enhancing skills and promoting local income distribution and socio-economic harmonization. It appears also, generally, increasing tourism in areas with geographical indications, beyond the diversification of production and therefore the preservation of biodiversity, local skills and natural resources (Brazil, 2008).

From the point of view of consumers, Chaddad (1995) highlights that the GI protects against deceptive practices related to the use of indications of origin or name of any product. Furthermore, the $\mathrm{Gl}$ allows the consumer to identify the product perfectly among others on the market (Pistorello, 2006).

Finally, products with Gls have known origin and certified not only by the data on the label, but also through the control system appropriate to that subject (Soeiro, 2005), highly secure. This control, including qualitative improvement, can stimulate them. Furthermore, increased participation in the cycle of marketing products can promote the elevation of its technical level (Pistorello, 2006).

\section{MATERIALS AND METHODS}

At first, the research consisted of analysis of secondary sources such as bibliographic references, laws, decrees, resolutions and surveys from other sources. In the second stage, references analyzed served as support for exploration of the issues raised.

The research was constituted as an exploratory study and documentary analysis. We have collected information regarding deposits and certificates of geographical indications granted by Brazil's National Institute of Industrial Property (INPI) in the last 14 years, including the period from 1997 to 2011. Subsequently, data were analyzed in detail and tabulated using Microsoft Excel 2007.

\section{RESULTS AND DISCUSSION}

Figure 1 presents the scenario of deposits and registrations granted geographical indications in Brazil over the past 14 years. Table 1 details the Gls which were granted.

Out of the 49 deposits of applications for certification of Gls in Brazil, only 18 were granted until 2011 (Figure 1). Lack of information, dissemination and industrial property requirements regarding Gls, and especially by the lack of infrastructure products and production potential of public policies seem to be the issue. From 2009 to 2011 there was a significant concession of records, thanks to the work of entities such as INPI, SEBRAE (Agency for Support to Entrepreneurship and Small Business Owners) and the Ministry of Agriculture who plotted strategies to leverage the number of records in Brazil.

The Ministry of Agriculture has created a Coordination Incentive Geographical Indications of Agricultural Products, titled (Coordination of Incentives to Geographical Indications - CIG / MAPA). The actions of the Federal Ministry of Agriculture Superintendents in the States in 2010 resulted in the expansion of the scope to other distinctive collective. In the States, there was coordination with other institutions, participation in forums (Bahia, Paraíba, Pará, Rio de Janeiro and Espírito Santo), raise awareness of producers, cooperation in education and training process. Still have important actions in the state of Bahia with potential Gls, such as the Region of Cachaça Abaíra, Cocoa Region Southern Bahia, Coffee Region Western Bahia Cigar Region Cruz das Almas and flour. 


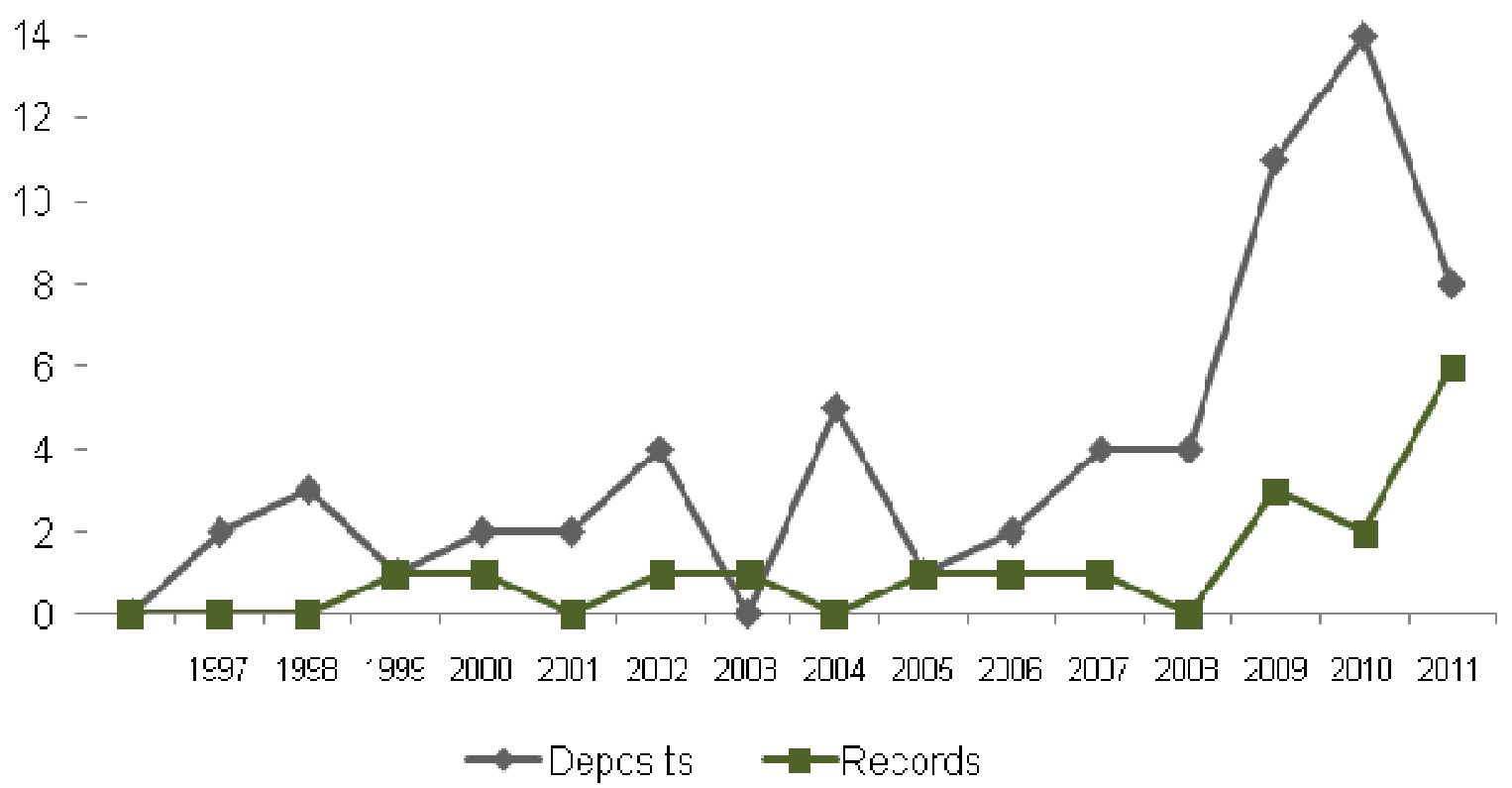

Figure 1. Deposits and records of Gls by INPI. Source: Database of the INPI (2012).

Table 1. Records of Gls by INPI.

\begin{tabular}{lllll}
\hline Year & Gl granted in Brazil & Product & Country & Specimens \\
\hline 1999 & Região dos Vinhos Verdes & Wines & Portugal & DO \\
2000 & Cognac & Cognac or brandy wine distillate Wines & France & DO \\
2002 & Vale dos Vinhedos & Red, white and sparkling wines & Brazil & IP \\
2003 & Franciacorta & Wines, sparkling wines and alcoholic bevarages & Italy & DO \\
2005 & Região do Cerrado Mineiro & Coffee & Brazil & IP \\
2006 & Pampa Gaúcho da Campanha Meridional & Meat and compounds & Brazil & IP \\
2007 & Paraty & Sugar cane brandy and bluish sugar cane brandy & Brazil & IP \\
2009 & San Daniele & Presento & Italy & DO \\
2009 & Vale do Sinos & Finished leather & Brazil & IP \\
2009 & Vale do Submédio São Francisco & Grapes and mangos & Brazil & $\mathbb{P}$ \\
2010 & Pinto Bandeira & Red, white and sparkling wines & Brazil & $\mathbb{P}$ \\
2010 & Litoral Norte Gaúcho & Rice & Brazil & DO \\
2011 & Serra da Mantiqueira & Coffee & Brazil & $\mathbb{P}$ \\
2011 & Costa Negra & Shrimps & Brazil & DO \\
2011 & Jalapão & Handmade items using Golden Grass & Brazil & $\mathbb{P}$ \\
2011 & Pelotas & Candies & Brazil & P \\
2011 & Goiabeiras & Clay pots & Brazil & $\mathbb{P}$ \\
2011 & Serro & Artesanal Cheese made in Minas Gerais State & Brazil & IP \\
\hline
\end{tabular}

Source: Database of the INPI (2012).

The low number of registration also happened because many applicants do not represent the region that the GI was given. IN order to apply for this certification in Brazil, according to Article 5 of the IPL enterprises there should be Associations/Institutes, a legal entity representing the community, or legal representative of the community legitimized the exclusive use of the geographical name and established in their territory.

As in Table 1, the 18 IGs are not granted some residents, other countries have deposits in Brazil, for example, Portugal (PT) with the IG of the Vinho Verde Region, the first recorded in 1999 in Brazil, another 
country is France (FR) with IG Cognac, granted in 2000, and finally Italy (IT) with two certifications, the Franciacorta in 2003 and San Daniele in 2009. Other countries have also made deposits and are awaiting the grant of registration.

Records provided so far, 6 of them are of denomination of origin (DO) and 12 of indication of origin, that because the IGs DO depend more physical than social context, this factor exists for a lower number.

One of the greatest GI of Industrial Property is Vale dos Vinhedos, the first resident granted, which produces red, white and sparkling wines. They account for $20 \%$ of fine wines and $25 \%$ of domestic sparkling wines. They are responsible for an annual average from 10 to 12 million bottles. They also prepare juice and other grape derivatives, offering products tastings. They conduct guided tours with explanation of the production process. The flow of visitors has been increasing in this region, Vale dos Vinhedos. In 2001, there were 45 thousand visitors, and in 2009, such number reached 182,229 visitors.

The Geographical Indication for the region of Cerrado Mineiro, which produces coffee, is in charge of $50 \%$ of coffee production in Brazil. It was the first region to undertake collective efforts in image enhancement as Brazilian coffee.

In 2011 there were a significant number of records, totaling 6. This is the special attention of the INPI for applicants in order to assist in obtaining GI within other important entities.

\section{Conclusion}

Among the rights related to Industrial Property, geographical indication raises as a mean of improving the social and economic development of any society. Some countries have been using judicial protection sponsored by geographical indication as a way of turning their products into more competitive ones for years. Such procedure promotes improvements in less developed regions. In Brazil, such theme is still new and it does need to be better understood.

One of the greatest difficulties that international and national protection procedures have been faced is related to the diversity of national concepts for geographical indication. Nevertheless, the main point is still the same: offering protection to names of local products which contributes to cultural identity of a nation or a region.

In Brazil, geographical indication discussion is on an initial level. It is necessary that manufacturers, business people and Brazilian consumers recognize and valorize origin indications in order to demonstrate the importance of the government actions towards the spread of such theme all over the country.

Some actions with such purpose have been done as well as researched on, the relation between product and territory, aggregated value to products and services with indications signed by INPI. The search for Brazilian products with real potential of being recognized by geographical indication has also been done by Ministry of Agriculture, Livestock and Food Supply of Brazil (MAPA) and by Brazilian Service of Support for Micro and Small Businesses.

The challenges for the Brazilian Government are the creation of explicit public policies for support of geographical indications from the structuration of the document and the deposits on INPI to the promotion and protection at an international level. For the manufacturers, the challenges are the protection of the conceded geographical indications in international markets.

The absence of representatives associations is responsible for making the process of concessions of such registers difficult in Brazil. Multidisciplinary studies with diverse organs and the creation of public policies may guarantee the increase of such registers, as well as their valorization. The set of efforts for such development should be focused on critic mass formation in order to promote the construction of national politics based on regional development.

However, geographical indications can be a quality indicator of quality for Brazilian agribusiness. Besides perceiving quality, it also guarantees to the consumer a more reliable and safe product. From such differential attributes, it is possible to orientate this product to specific markets aggregating value.

\section{ACKNOWLEDGEMENT}

Thanks to National Council for Scientific and Technological Development (CNPq) for financing this research.

\section{REFERENCES}

Allaire G, Sylvander B (1997). Qualité spécifique et systèmes d'innovation territoriale. Cah d'Economie et Sociologie Rurales 44:29 59.

Aroeira LJM, Alves AA, Lana AMQ (2009). Análise de desempenho econômico da produção orgânica de leite: estudo de caso no Distrito Federal. Ciênc. Agrotec. 33(2):567-573.

Aurier P, Fort F, Sirieix L (2005). Exploring terroir product meaning for the consume. Anthropol. Food. P. 4.

Azevedo DB, Malafaia GC, Pedrozo EA (2012). Should interorganizational relationships in agribusiness be guided by consumer or by stakeholders? Afr. J. Bus. Manage. 6(3):745-755.

Batt PJ, Dean A (2000). Factors influencing the consumer's decision. Aust NZ W. Indus. J. 15(4):34-41.

Benko G, Pecquer B (2001). Les ressources de territoires et les territoires de ressources. Finisterra 36(71):7-19.

Bérard L, Marchenay P (2008). From Localized Products to Geographical Indications: Awareness and Action. CNRS.

Brazil (1996). Lei de Propriedade Industrial do Brasil no. 9.279, de 14 de maio de 1996. In:

<http://www.planalto.gov.br/ccivil_03/leis/L9279.htm>. Access in: 26 jul. 2012.

Brazil (2008). Ministério da Agricultura, Pecuária e Abastecimento. Guia 
para a solicitação de registro de indicação geográfica para produtos agropecuários. In: <http://www.agricultura.gov.br/pls/portal/docs/PAGE/MAPA/SERVIC OS/IG_PRODUTOS_AGROPECUARIOS/CONSTRUINDO_AS_IG/G UIA\%20IG\%20FINAL_0.PD>. Access in: 21 jul. 2012.

Bruch KL (2008). Indicações geográficas para o Brasil. Jornal A Vindima - O Jornal da Vitivinicultura Brasileira, Flores da Cunha: Século Novo. pp. 16-17.

Cerdan C, Vitrolles D (2008). Valorisation des produits d'origine: contribution pour penser le développement durable dans la Pampa Gaúcha au Brésil. Géocarrefour. 83(3):191-200.

Chaddad FR (1995). Denominações de origem controlada: um projeto de pesquisa. REGE Rev. Gest. (Impr). 1(1):1-6.

Charlier C, Ngo MA (2012). Geographical indications outside the European Regulation on PGls, and the rule of the free movement of goods: Lessons from cases judged by the Court of Justice of the European Communities. Eur. J. Law Econ. 34(1):17-30.

Darby MR, Karni E (1973). Free competition and the optimal amount of fraud. J. Law Econ. 16(1):67-88.

Inpi (2012). Instituto Nacional de Propriedade Industrial. Principais estatísticas relativas ao sistema de propriedade intelectual e aos serviços oferecidos até 2011: Depósitos e as concessões de Indicação Geográfica. In: <http://www.inpi.gov.br/images/stories/IG_Portal.pdf>. Access in 15 jul. 2012.

Fandos C, Flavián C (2006). Intrinsic and extrinsic quality attributes, loyalty and buying intention: an analysis for PDO product. Br. Food J. 108(8):646-662.

Jacobs H, Zulu C (2012). Reaping the benefits of value innovation: Lessons for small agribusinesses in Africa. Afr. J. Bus. Manage. 6(33):9510-9523.

Jover AJ, Montes FJL, Fuentes MMF (2004). Measuring perceptions of quality in food products: the case of red wine. Food Qual. Prefer. 15(5):453-446.

Lopes MA, Santos G (2007). Principais dificuldades encontradas pelas certificadoras para rastrear bovinos. Ciênc. Agrotec. 31(5):15521557.
Lopes Neto JP, Nascimento JWB, Calil Junior C (2008). Análise estrutural de silos metálicos prismáticos. Ciênc. Agrotec. 32(4):12521258.

Mancini MC (2013). Localised Agro-Food Systems and Geographical Indications in the Face of Globalisation: The Case of Queso Chontaleño. Sociol. Ruralis. 53(2):180-200.

Menapace L, Moschini G (2012). Quality certification by geographical indications, trademarks and firm reputation. Eur. Rev. Agric Econ. 39(4):539-566

Mérel P, Sexton RJ (2011). Will geographical indications supply excessive quality? Eur. Rev. Agric. Econ. 39(4):567-587.

Nicolas F, Valceshini E (1993). Agro-alimentaire et qualite: questions aux sciences sociales. Écon. Rurale. 217(1):5-11.

Orth UR, Krska P (2002). Quality signals in wine marketing: the role of exhibition award. Int. Food Agr. Manage. Rev. 4:385-397.

Paula J (2004). Territórios, redes e desenvolvimento. In: Lages V. et al. (Org.). Territórios em movimento: Cultura e identidade como estratégia de inserção competitiva. Rio de Janeiro: Relume Dumará; Brasília, DF: SEBRAE. pp. 73-84.

Pistorello $N$ (2006). Sub-projeto denominação de origem controlada. Projeto VICTUR- Valorização do turismo integrado à identidade cultural dos territórios. Sebrae-RS.

Rangnekar D (2011). Remaking place: The social construction of a geographical indication for Feni. Environ Plann. A. 43(9):2043-2059.

Soeiro A (2005). Denominações de origem e indicações geográficas protegidas: a sua importância. In <http://www.pluridoc.com/Site/FrontOffice/Default.aspx?module=Files /FileDescription\&ID=1910\&state=FD>. Access in: 12 jul. 2012.

Tehrani PM, Manap NA (2013). Urgency and benefits of protecting Iranian carpets using geographical indications. J. Intell. Prop. Rights 18(1):72-82.

Tonietto JO (1993). Conceito de denominação de origem: uma opção para o desenvolvimento do setor vitivinícola brasileiro. Bento Gonçalves: EMBRAPA-CNPUV. (Embrapa-CNPUV- Documento 8):20. 